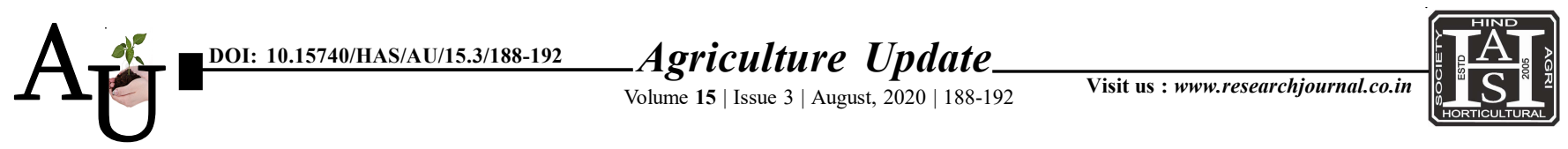

ISSN-0973-1520

\title{
Research Article: Effect of date of harvesting on yield and quality of different rice varieties
}

Article Chronicle :

Received :

21.02.2020;

Revised:

09.06.2020;

Accepted :

10.07.2020

KEY Words :

Harvesting time,

Rice, Hulling, Milling, Head rice recovery
Author for correspondence :

K. Anny Mrudhula

Saline Water Scheme, Bapatla (A.P.) India

Email: anny.mrudhula1@ gmail.com

See end of the article for authors' affiliations
SUMMARY : Greater attention should be paid for increasing the yield per unit area by growing modern varieties of rice through improved cultivation practices. An experiment was conducted for investigating the effect of variety and date of harvesting on yield performance of modern rice varieties during Kharif, 2012 at Agricultural Research Station, Bapatla. The experiment was laid out in a split-plot design with three replications. Main treatments comprised of four rice varieties namely, BPT 5204, BPT 2270, BPT 2231, NLR 34449, NLR 28523 and MTU 1010 and sub treatments comprised of three time of harvesting viz., 25, 30 and 35 days after flowering. Plant growth, yield attributes, yield and quality of rice varieties were significantly influenced by different dates of harvesting. BPT 2270 was found significantly superior to all other varieties in respect of effective tillers, grains panicle ${ }^{-1}$, grain yield, straw yield and hulling per cent, milling per cent and head rice recovery. Among three harvesting times, the highest grain yield $\left(6250 \mathrm{~kg} \mathrm{ha}^{-1}\right)$ and straw yield $\left(7314 \mathrm{~kg} \mathrm{ha}^{-1}\right)$ were obtained when the crop was harvested at 30 days after flowering. The interaction effect of variety and date of harvesting was significant in respect of grain and straw yield. The highest grain yield $\left(7771 \mathrm{~kg} \mathrm{ha}^{-1}\right)$ was observed in BPT 2270 when harvested at 30 days after flowering. Therefore, optimum date of harvesting for higher grain yield may be 30 days after flowering for avoiding immature stage as well as shattering loss.

How to cite this article : Mrudhula, K. Anny and Veni, B. Krishna (2020). Effect of date of harvesting on yield and quality of different rice varieties. Agric. Update, 15(3): 188-192; DOI : 10.15740/HAS/AU/15.3/188-192. Copyright@2020: Hind Agri-Horticultural Society. 
those countries is higher due to their adoption of improved varieties, modern farming technology and sophisticated cultural practices. Therefore, India has a tremendous scope of increasing her total production by augmenting per hectare yield through the use of modern technology. Moreover, Seed is a vital input of riceproduction which largely determines both the quantityand quality. Improvement of rice production can be achieved through different agronomic practices and treatments. Seed maturity has critical implications for seed quality in terms of their germinability and vigor. In timely harvesting of rice ensures good quality with higher yield (Ali et al., 1990). Grain yield and its quality depend on the right judgment at harvesting. Farmers usually harvest transplant rice at or beyond the full maturity stage and keep it in the field quite along time. This risk is more acute especially at the harvesting time of rice in Kharif season. Some times natural disaster and its area can be predicted before several days of its attacking. If the information about seed quality in relation to degree of seed maturity is available, seed crop can also be harvested at the reasonable time to overcome certain contingent situation. Hence, present study was under taken to evaluate the performance of rice varieties through different harvesting times to get quality seed with high yield. Harvesting time of rice crop is very important in respect of yield and yield contributing characters. If rice is harvested at proper time and stored in a proper way, 10-15 per cent more production will be obtained (CDP, 1995). Early or immature harvest may lead to low yield. Delayed harvesting results in high shattering, lodging, broken rice, decline yield of head rice (Bhatti et al., 1983). In the light of the above information the present study was undertaken to evaluate the varietal effect on yield and yield attributes under various dates of harvesting.

\section{Resources AND Methods}

The experiment was conducted during Kharif, 2012 at Agricultural Research Station, Bapatla during Kharif, 2012. The experiment was laid out in a split-plot design. The main treatments were rice varieties viz., BPT 5204, BPT 2270, BPT 2231, NLR 34449, NLR 28523 and MTU 1010. The sub treatments were date of harvestings viz., 25 days after flowering (DAF), $30 \mathrm{DAF}$ and $35 \mathrm{DAF}$. The unit plot size was $6.0 \mathrm{~m} \times 5.4 \mathrm{~m}$. Variety was randomly placed in the main plot and date of harvesting in sub plot. Each treatment was replicated thrice. Space between replications and between plots were $1.0 \mathrm{~m}$ and $0.5 \mathrm{~m}$, respectively. Planting space was $20 \mathrm{~cm} \times 15 \mathrm{~cm}$ between the rows and plants. Nitrogen was applied as per the treatments in three equal splits in the form of urea. First split of nitrogen was applied as basal dose at the time of planting of the crop remaining two equal splits of nitrogen was broadcasted at maximum tillering and panicle initiation stages. Phosphorus was applied at the rate of $60 \mathrm{~kg} \mathrm{P}_{2} \mathrm{O}_{5} \mathrm{ha}^{-1}$ in the form of single super phosphate as basal and potassium $40 \mathrm{~kg} \mathrm{~K}_{2} \mathrm{O} \mathrm{ha}^{-1}$ in the form of muriate of potash was applied in two equal splits as basal dose at the time of transplanting and panicle initiation stage. Gap filling, weeding, irrigation and other necessary intercultural operations were done in proper time. Harvesting was done plot wise at 25, 30 and 350 DAF. Five hills were selected randomly from each unit plot for taking yield component data at harvest. One $\mathrm{m}^{2}$ area from each plot was selected from the central portion and was cut manually from the ground level to take grain and straw yields. The harvested crop of each plot was separately bundled, properly tagged and then brought to the threshing floor. The harvested crops were threshed manually. The grain was cleaned and dried to a moisture content of 14 per cent. Straws were sun dried properly. Data recorded for yield parameters were compiled and tabulated in proper form for statistical analysis (Gomez and Gomez 1984).

\section{ObSERVATiOnS AND ANALYSIS}

The findings of the present study as well as relevant discussion have been summerized under following heads:

\section{Effect of variety :}

The effect of variety was found to be significant in respect of all the yield and yield contributing characters. Results of the experiment revealed that significantly the highest plant height $(128.6 \mathrm{~cm})$ was recorded with NLR 28523 and the lowest plant height $(80.6 \mathrm{~cm})$ was found in NLR 34449 variety. The maximum number of effective tillers hill ${ }^{-1}$ was observed in BPT 2270 (13) variety followed by BPT 2231 variety (12) which was significantly superior to NLR 28523. Significantly the highest panicle length $(24.4 \mathrm{~cm})$ was observed with BPT 2270 variety and the lowest panicle length $(20.5 \mathrm{~cm})$ was recorded with NLR 34449 variety. BPT 2270 produced the highest 
number of filled grains panicle ${ }^{-1}$ (237) followed by BPT 2231 variety and the lowest number of filled grains panicle $^{-1}$ (145) was produced by MTU 1010. The results expressed that the highest test weight (20.4 g) was obtained in MTU 1010 and the lowest weight was $(14.4 \mathrm{~g})$ in BPT 5204. The variation in 1000-grain weight might be due to differences of length and breadth of the grain that were partially controlled by genetic make-up of the varieties under study. The highest grain yield (6846 $\left.\mathrm{kg} \mathrm{ha}^{-1}\right)$ in BPT 2270 was mostly due to its more number of effective tillers, longest panicle length and more number of grains panicle $^{-1}$ (Table 1). The lowest yield (4804 $\mathrm{kg} \mathrm{ha}^{-1}$ ) was found in MTU 1010 because of its lower effective tiller hill-1 and lower number of grains penicle ${ }^{-1}$. The highest straw yield was found in BPT $2270(7100 \mathrm{~kg}$ $\left.\mathrm{ha}^{-1}\right)$ and the lowest was in NLR $34449\left(5761 \mathrm{~kg} \mathrm{ha}^{-1}\right)$ in Table 2. BPT 2270 produced significantly the highest hulling per cent $(73.2 \%)$ milling per cent $(65.2 \%)$ and head rice recovery $(57.1 \%)$ and the lowest hulling per cent $(70.0 \%)$, milling per cent $(60.3 \%)$ and head rice recovery $(54.4 \%)$ with NLR 34449 variety.

\section{Effect of date of harvesting:}

The effect of different dates of harvesting showed that significant effect on panicle length, number of grains per panicle, test weight and grain yield at $30 \mathrm{DAF}$ but there is no significant effect on plant height, total effective tillers hill ${ }^{-1}$. The effect of harvesting date was significant in respect of yield and all yield contributing characters. Significantly the highest panicle length $(23.9 \mathrm{~cm})$, maximum number of filled grains panicle ${ }^{-1}(210)$, highest test weight $(18.5 \mathrm{~g})$, highest grain yield $\left(6250 \mathrm{~kg} \mathrm{ha}^{-1}\right)$ and highest straw yield (7314 $\left.\mathrm{kg} \mathrm{ha}^{-1}\right)$ when the crop was harvested at $30 \mathrm{DAF}$. Grain yield per panicle and germination (\%) were found high under $30 \mathrm{DAF}$ reported by Baktiar et al. (2013). Similar conclusions were reported by Kady et al. (1992); Surek et al. (1996) and Asano et al. (1999). The lowest panicle length $(22.7 \mathrm{~cm})$, minimum number of filled grains panicle ${ }^{-1}(198)$, lowest test weight (17.6 g), lowest grain yield $\left(5257 \mathrm{~kg} \mathrm{ha}^{-1}\right)$ and straw yield (6143 $\left.\mathrm{kg} \mathrm{ha}^{-1}\right)$ were recorded when the crop was harvested at 25 DAF (Table 2). The lowest yield was obtained for harvesting at $25 \mathrm{DAF}$ due to immaturity of spikelet. All of the above parameters

\begin{tabular}{|c|c|c|c|c|c|}
\hline Main treatments & $\begin{array}{l}\text { Plant height } \\
(\mathrm{cm})\end{array}$ & $\begin{array}{c}\text { No. of productive } \\
\text { tillers/plant }\end{array}$ & $\begin{array}{c}\text { Panicle length } \\
(\mathrm{cm})\end{array}$ & $\begin{array}{c}\text { No. of filled } \\
\text { grains/panicle }\end{array}$ & $\begin{array}{c}\text { Test weight } \\
(\mathrm{g})\end{array}$ \\
\hline \multicolumn{6}{|l|}{ Varieties } \\
\hline MTU 1010 & 90.8 & 10 & 22.6 & 145 & 20.4 \\
\hline NLR 34449 & 80.6 & 10 & 20.5 & 162 & 15.4 \\
\hline ВРТ 5204 & 88.3 & 9 & 21.9 & 171 & 14.4 \\
\hline BРТ 2231 & 101.8 & 12 & 22.7 & 228 & 18.3 \\
\hline NLR 28523 & 128.6 & 8 & 22.0 & 168 & 19.1 \\
\hline BPT 2270 & 104.7 & 13 & 24.4 & 237 & 15.5 \\
\hline S.E. \pm & 2.4 & 1.1 & 0.6 & 13.3 & 0.1 \\
\hline C.D. $(\mathrm{P}=0.05)$ & 6.8 & 3.2 & 1.7 & 38.5 & 0.4 \\
\hline CV (\%) & 5.1 & 5.3 & 5.3 & 15.3 & 11.9 \\
\hline \multicolumn{6}{|l|}{ Sub treatments } \\
\hline 25 days after flowering & 98.2 & 13 & 22.7 & 207 & 17.6 \\
\hline 30 days after flowering & 101.4 & 11 & 23.9 & 210 & 18.5 \\
\hline 35 days after flowering & 94.6 & 11 & 22.9 & 198 & 17.9 \\
\hline S.E. \pm & 2.2 & 1.7 & 0.2 & 2.4 & 0.04 \\
\hline C.D. $(\mathrm{P}=0.05)$ & NS & NS & 0.9 & 7.2 & 0.13 \\
\hline CV (\%) & 6.8 & 6.7 & 5.8 & 9.6 & 4.7 \\
\hline \multicolumn{6}{|l|}{ Interaction } \\
\hline S.E. \pm & 14.0 & 3.0 & 1.5 & 13.1 & 0.2 \\
\hline C.D. $(\mathrm{P}=0.05)$ & NS & NS & NS & 36.3 & 0.5 \\
\hline
\end{tabular}

$\mathrm{NS}=$ Non-significant 
K. Anny Mrudhula and B. Krishna Veni

\begin{tabular}{|c|c|c|c|c|c|c|c|}
\hline Main treatments & Grain yield (kg/ha) & Straw yield & $\mathrm{kg} / \mathrm{ha})$ & Hulling \% & Milling \% & Head & ice recovery $\%$ \\
\hline \multicolumn{8}{|l|}{ Varieties } \\
\hline MTU 1010 & 4804 & \multicolumn{2}{|l|}{5864} & 71.3 & 67.6 & \multicolumn{2}{|r|}{61.4} \\
\hline NLR 34449 & 5064 & \multicolumn{2}{|l|}{5761} & 70.0 & 60.3 & \multicolumn{2}{|r|}{54.4} \\
\hline BPT 5204 & 5854 & \multicolumn{2}{|l|}{6911} & 72.4 & 63.2 & \multicolumn{2}{|r|}{54.8} \\
\hline BPT 2231 & 5980 & \multicolumn{2}{|l|}{7005} & 72.9 & 63.0 & \multicolumn{2}{|r|}{55.3} \\
\hline NLR 28523 & 5772 & \multicolumn{2}{|l|}{6788} & 71.6 & 61.0 & \multicolumn{2}{|r|}{54.4} \\
\hline BPT 2270 & 6846 & \multicolumn{2}{|l|}{7100} & 73.2 & 65.2 & \multicolumn{2}{|r|}{57.1} \\
\hline S.E. \pm & 427 & \multicolumn{2}{|l|}{435} & 1.4 & 2.0 & \multicolumn{2}{|r|}{1.2} \\
\hline C.D. $(P=0.05)$ & 1232 & \multicolumn{2}{|l|}{1305} & 4.1 & 5.9 & \multicolumn{2}{|r|}{3.5} \\
\hline CV (\%) & 12.8 & \multicolumn{2}{|l|}{14.1} & 4.2 & 6.9 & \multicolumn{2}{|r|}{4.7} \\
\hline \multicolumn{8}{|l|}{ Sub treatments } \\
\hline 25 days after flowering & 5257 & \multicolumn{2}{|l|}{6143} & 66.7 & 60.4 & \multicolumn{2}{|r|}{51.4} \\
\hline 30 days after flowering & 6250 & \multicolumn{2}{|l|}{7314} & 73.6 & 63.0 & \multicolumn{2}{|r|}{54.8} \\
\hline 35 days after flowering & 5654 & \multicolumn{2}{|l|}{6458} & 72.8 & 62.1 & \multicolumn{2}{|r|}{54.4} \\
\hline S.E. \pm & 187 & \multicolumn{2}{|l|}{276} & 0.8 & 0.3 & \multicolumn{2}{|r|}{0.6} \\
\hline C.D. $(P=0.05)$ & 564 & \multicolumn{2}{|l|}{830} & 3.1 & 1.2 & & 1.9 \\
\hline CV (\%) & 9.7 & 14.2 & & 3.3 & 1.5 & & 3.8 \\
\hline Interaction & & & & & & & \\
\hline C.D. $(P=0.05)$ & 739 & 926 & & 2.5 & 3.5 & & 2.5 \\
\hline $\mathrm{CV}(\%)$ & NS & NS & & NS & NS & & NS \\
\hline $\mathrm{NS}=$ Non-significant & & & & & & & \\
\hline Table 3: Effect of date & vesting schedules 0 & n grain yield of dif & ferent rice $v$ & & & & \\
\hline Harvesting schedules & & & Varie & & & & \\
\hline & MTU 1010 & NLR 34449 & BPT 5204 & BPT 2231 & NLR 28523 & BPT 2270 & Mean \\
\hline 25 days after flowering & 3977 & 4633 & 6254 & 5500 & 5067 & 6100 & 5257 \\
\hline 30 days after flowering & 5597 & 5517 & 5833 & 6383 & 6400 & 7771 & 6250 \\
\hline 35 days after flowering & 4840 & 5033 & 5433 & 5476 & 6059 & 5851 & 5654 \\
\hline Mean & 4804 & 5064 & 5854 & 5980 & 5772 & 6846 & \\
\hline & S.E. \pm & C.D. $(\mathrm{P}=0.05)$ & $\mathrm{CV}(\%)$ & & & & \\
\hline Harvesting schedules & 427 & 1232 & 12.8 & & & & \\
\hline Varieties & 187 & 564 & 9.7 & & & & \\
\hline Interaction & 520 & 1561 & 10.4 & & & & \\
\hline
\end{tabular}

gradually increase upto full heading and thereafter decreased due to shattering and low moisture content of seeds. Significantly the highest hulling per cent $(73.6 \%)$ milling per cent $(63.0 \%)$ and head rice recovery $(54.8$ $\%)$ was recorded when crop was harvested at 30 days after flowering and the lowest hulling per cent (66.7 \%) milling per cent $(60.4 \%)$ and head rice recovery $(51.4$ $\%$ ) was obtained when crop was harvested at 25 days after flowering.

Interaction effect of variety and date of harvesting: Interaction of variety and date of harvesting was significant in respect of filled grains per panicle, test weight and grain yield. The highest grain yield was recorded with BPT 2270 variety at 30 days after flowering (7771 kg ha-1) and the lowest grain yield was obtained with MTU 1010 variety at 25 DAF (3977 kg ha $^{-1}$ ) in Table 3.

\section{Conclusion:}

From the results and discussion it has been found that the highest grain yield $\left(6846 \mathrm{~kg} \mathrm{ha}^{-1}\right)$ was obtained by BPT 2270 when it was harvested at 30 DAF. Therefore, it can be concluded that BPT 2270 has a great 
potentiality to produce higher yield than other varieties and it should be harvested at 30 DAF for avoiding immature stage as well as shattering loss. Finally, it may be concluded that harvesting at 30 to 35 days after flowering (DAF) was found to be suitable for all of the grain characters of the tested varieties. These times are suitable for quality of seed. Maturity period and harvesting time is a so much important for quality seed production and escape from contingent situation.

Authors' affiliations :

B. Krishna Veni, Saline Water Scheme, Bapatla (A.P.) India

\section{REFERENCES}

Ali, A., Majid, A., Rehman, H. and Sagar, M. A. (1990). Milling recovery of Basmati as affected by threshing methods and crop harvesting time. Pakistan J. Agric. Res., 11: 7-12.

Asano, H., Isobe, K. and Tsuboki, Y. (1999). Effect of harvesting date on the quality and palatability of paddy rice cultivated by Aig Amo Duck Farming System. Japanese J.Crop Sci., 68: 375-378.

Baktiar, M.K.H., Siddique, M.A., Khalequzzaman, M., Bhuiya,
A. and Islam, M.Z. (2013). Effect of maturity period and harvesting time on quality and yield in breeder seed of rice (Oryza sativa L.) Eco-friendly Agric. J., 6 (11): 249-252.

Bhatti, I.M., Khuhro, G.A. and Blach, M.H. (1983). Influence of time of harvest on yield and milling quality of rice. Sind $J$. Agric. Res., 3(1): 30-35.

CDP (Crop Diversification Programme) (1995). Beez Projukti Nirdeshika (in Bangli). Dept. Agril. Ext. Ministry of Agriculture Bangladesh. pp. 5.

Gomez, M.A. and Gomez, A.A. (1984). Statistical procedures for Agricultural Research. John Wiley and Sons. New York, Chichesten, Brisbane, Torobto. 97-129, 207-215.

Jagtap, D.N., Mahadkar, U.V. and Chavan, L.S. (2012). Productivity and economics of rice influenced by different crop establishment methods and fertilizer sources. Agricultural $J$., 7:32-36.

Kady, A.A., El-Hissewy, A.A. and El-Serafy, A.M. (1992). Grain quality characters of rice as affected by harvesting time. Proc. $5^{\text {th }}$ Conf. Agron. Zagazig, 13-15 Sept., 1: 80-86.

Surek, H.H., Aydin, M., Negis and Kushu, H. (1996). Determining the optimum rice harvesting time. International Rice Common News letter, 45: 45-48. 